Jorge Costadoat, S.J.

Profesor de la Facultad de Teología

Pontificia Universidad Católica de Chile

\title{
La fe de Jesús, fundamento de la fe en Cristo
}

\section{INTRODUCCIÓN}

La fe cristiana plasma en un credo pero, ante todo, es un modo de creer. La fe cristiana enhebra otra vez el credo de Israel en la medida que mueve a confiar y a obedecer a un Dios que merece ser creído. Aquello que hace las veces de fides quae, el concepto del Dios de la Antigua y de la Nueva Alianza, el Dios de la creación y de la historia, proviene de una experiencia de Dios mismo y sirve a nuevas experiencias suyas. La fides qua, la experiencia del amor, la liberación y perdón de Dios, constituye el único fin de la teología cristiana y el remedio exacto contra la esclerosis del cristianismo.

Por esta razón la fe de Jesús prepascual constituye el paradigma de la fe cristiana en estos dos aspectos, el subjetivo y el objetivo. Lo que la Iglesia cree de Cristo, el credo, hunde sus raíces en el modo que tuvo Jesús de creer en Dios (1). Habría sido un engaño que la Iglesia inventara su creencia. Pero sin la experiencia espiritual de la Iglesia salvaguardada en su credo, jamás nos habríamos enterado de la experiencia espiritual de Jesús. No habríamos conocido el camino que nos abrió ni la manera de recorrerlo. Entre la experiencia de Dios de Jesús y la experiencia de

(1) El presente ensayo no tiene por objeto demostrar que Jesús tuvo fe. Este asunto ha sido suficientemente estudiado. Hans Urs von Balthasar, La Foi du Christ. Cinq approches christologiques (Paris, 1968); Karl Rahner, "Considérations dogmatiques sur la psychologie du Christ", Exégèse et dogmatique, Paris, DDB, 1966, 185-210; Bernard Sesboüé, “ Science et conscience du Jésus prépascal "Pédagogie du Christ. Eléments de christologie fondamentale, Cerf, Paris, 1996, pp. 141-175 ; Peter Hünermann,Cristología (Barcelona, 1997); Jacques Guillet, La foi du JésusChrist (Paris, 1980); Manuel Gesteira, "La fe-fidelidad de Jesús, clave central de la cristología", en Gabino Uríbarri (ed.) Fundamentos de teología sistemática, Universidad Pontificia Comillas, Madrid, 2003, pp. 93-135; Jacques Dupuis, Introducción a la cristología (Pamplona, 1994); Jon Sobrino, Jesucristo liberador (Madrid, 1991); Hans Kessler, Manual de cristología (Barcelona, 2003); Giovanni Giammarrone, Gesù di Nazaret Messia del Regno e Figlio di Dio (Padova, 1995); Olegario González de Cardedal, Cristología (Madrid, 2001); Gerald O'Collins, Para interpretar a Jesús (Madrid, 1986); Christian Duquoc, Cristología (Salamanca, 1981); Michael Cook, The Jesus of Faith (New York, 1981); Leonardo Boff, Jesucristo el Liberador: ensayo cristológico para nuestro tiempo (Buenos Aires, 1974); Carlos Palacio, Jesucristo. Historia e interpretación (Madrid, 1978); Albert Nolan, Jesús antes do cristianismo (São Paulo, 1989); Romano Guardini, El Señor (Madrid, 1960); Joaquim Gnilka, Jesús de Nazaret (Barcelona, 1993); Bruno Forte, Jesús de Nazaret. Historia de Dios. Dios de la historia (Madrid, 1983); Walter Kasper, Jesús el Cristo (Salamanca, 1989). 
Cristo de la Iglesia, un mismo Espíritu establece la conexión y la compenetración vital que nutre a los cristianos contemporáneos. A lo largo de la historia de Israel, de la Iglesia y de la nuestra, ha debido prevalecer la vida espiritual que el Espíritu genera inmediatamente en cada creyente, pero que solo se hace inteligible para él mismo y para los demás en mediaciones culturales y religiosas que la encauzan (2).

Por otra parte el contenido de la fe en Dios es determinado históricamente. Dicho en breve, el judeocristianismo sabe que Dios es el "Dios de la vida". Yahvé, el Abbá de Jesús, ama la vida de Israel, la de Jesús y la nuestra. Esto es lo que hay que creer: Dios siempre quiere la vida, nunca la muerte. Si San Juan sostiene que "Dios es amor", la fe consiste en creer que Dios nos ama. Así de claro, pero no de fácil. La historia del pueblo elegido, la historia de la Iglesia y la historia humana, doquiera la encontremos, a menudo son un mentís del amor de Dios o de la bondad del Creador. Y si no lo son, así se lo percibe y se lo sufre. La tragedia griega, podríamos decir, todavía resiste al monoteísmo. Tantas veces, a tantos, la enfermedad, la venganza, la culpa y la muerte los persiguen como acosaron a los griegos las furias implacables. La fuerza de un mal infinito, enigmático, el espanto que produce, su horror, apagan a la humanidad y obligan a Dios mismo a comparecer en el sillón de los acusados. La fe judeocristiana no coincide con la pistis helénica (3). Pero se parece a ella, porque se parecen los tormentos que afligieron a los hombres de esos tiempos. Frente al mysterium iniquitatis los cristianos no confiesan que "Dios existe", sino que Dios es el "Dios de la vida" y el "Dios liberador". Lo hacen, sin embargo, con fatiga, venciendo la fatiga de una existencia permanentemente amenazada, apostando por el Dios de Jesús, por el Dios bueno, por el que Jesús apostó. Es que no es obvio que la creación tenga sentido o, dicho con mayor precisión, no es evidente que el mundo sea creación.

(2) La recuperación del carácter existencial de la fe en el siglo XX se debe a Soren Kierkegaard en buena medida (Escuela de cristianismo). Los cristianos del último siglo han recobrado la "contemporaneidad" con Cristo. Sin embargo, ingenuamente han creído poder prescindir de los que efectivamente le fueron "contemporáneos" y de los testigos de Cristo a lo largo de la historia

(3) La traducción de una experiencia de raigambre hebrea de Dios a términos griegos, no puede sino alertar a la teología. En un asunto tan delicado como el de la "fe", aun cuando el Nuevo Testamento utilice pistis, cabe recordar que la actitud en cuestión se configura en relación a conceptos bien distintos de Dios. De aquí que el uso de pistis ha podido perfectamente extraviar a las generaciones de cultura griega posteriores a las del Nuevo Testamento, y a la teología basada en ella. A este propósito Manuel Gesteira recuerda la feliz distinción Martín Buber (Dos modos de creer, 1950), filósofo judío, entre la fe más genuinamente judía entendida como fidelidad personal (emuna) a alguien (a Yahvé, el Dios bíblico), de la fe como pistis o asentimiento intelectual a algo (un conjunto de verdades, como a las que adhirió posteriormente el cristianismo en un ambiente helenístico). La fe veterotestamentaria tiene lugar en una relación de encuentro y de diálogo entre Dios y el hombre, activado por el amor-fidelidad de Dios que suscita en el hombre una respuesta equivalente. "Esta fe-emuna implica una seguridad y una firmeza absolutas, basadas en la veracidad y la fidelidad que Dios mismo es y que Él nos brinda: porque creo-confío en ti, te creo; y no viceversa" (Manuel Gesteira: "La fe-fidelidad de Jesús, clave central de la cristología”, en Gabino Uríbarri (ed.) Fundamentos de teología sistemática, Universidad Pontificia Comillas, Madrid, 2003, p. 99). La fe de Israel y la de cada uno de los israelitas es indisociable de la fidelidad de Dios a la alianza, el Dios "rico en misericordia y fidelidad" (Ex 34, 6). "A esta verdad-fidelidad (emet) divina responde sobre todo la fidelidad-confianza-fe (emuna) del creyente: y no como un mero asentimiento conceptual, sino como entrega radical en fidelidad personal y en respuesta a Dios como fidelidad absoluta él mismo" (o.c., p. 99). Es esta fe la que gesta en Israel la posibilidad de vivir el futuro como historia, en libertad y esperanza. 
A ratos solo predomina la "descreación" (4), la impresión del éxito de las ruinas y de la irracionalidad, contra la cual solo la fe puede triunfar. Pero no cualquier fe.

Este asunto tiene enorme relevancia. La Iglesia y la modernidad se han distanciado en buena medida porque, de una y otra parte, se han comportado como si la fe pudiese operar independientemente de la razón y viceversa. La razón moderna perfecciona los medios, pero pierde los fines. La Iglesia Católica insiste en los fines, pero tiene dificultades para poner los medios. Puesto que aquí la perspectiva es la de un anuncio del Evangelio a un mundo que sufre, el peligro inmediato no será tanto el racionalismo, aunque este no deje de serlo, cuanto el fideísmo que puede expresarse en fugas, reacciones sentimentales o en posturas proféticas pero irresponsables (5). Si iniciado el Tercer Milenio la Iglesia no encara esta amenaza, cualquier conversión que obtenga en el mundo actual, especialmente en el mundo en cuanto moderno, solo acumulará puntos en la cuenta del extravío. También otras veces las generaciones han tenido la impresión de un fin de mundo. Recuérdese el desmoronamiento del Imperio romano. Ayer como hoy, el fideísmo y su sustentación fundamentalista hacen presa fácil de los fieles, de los infieles y de numerosos pastores que sufren los males de la época.

En este artículo, la fe israelita que siguió el curso que Jesús le dio; la fe de Abraham, la de Job y la de los Macabeos que terminó por triunfar sobre la injusticia y la muerte con la resurrección de Jesús, debe ser considerada la fragua de la fe cristiana en su referencia fundamental a Dios y al mundo. Siendo que la fe bíblica en la resurrección de los muertos es primariamente la fe de los mártires, la resurrección de Jesús, la más inocente de las víctimas y el mártir de la fe por excelencia, obliga a asumir como horizonte más amplio de la experiencia cristiana de Dios la creencia en una "vida eterna" que, sin embargo, no se verifica sino como "justicia" para las víctimas (6). Es en el horizonte de la fe y la justicia que se hace necesario

(5) De cara al mal, tanto el fideísmo como el racionalismo ejercen una negación. El racionalismo teológico, fenómeno bastante más frecuente de lo que se piensa, encuentra algún lugar al mal en Dios (los ensayos trinitarios que no logran zafarse de la metafísica tradicional, por más que operen una historización de esta aproximación filosófica particular, suelen naturalizar la capacidad desquiciadora del mal). El fideísmo, por su parte, para negar el mal, niega la creación y toda criatura de la que pudiera provenir algún mal. Ambas negaciones, por distinto título y con diversas consecuencias, niegan la historia y la relación histórica con el Creador en términos de fe cristiana auténtica que no desespera de la creación, pero tampoco la sacraliza.

(6) Hans Kessler destaca que el origen de la creencia en la resurrección de los muertos se encuentra en la resistencia de los Macabeos, víctimas de la injusticia. A ellos, los justos tratados injustamente, se les promete la salvación no ya como retribución, sino como justificación y rehabilitación en virtud de la futura demostración de la soberanía de Dios sobre la historia, sobre la vida y la muerte (cf. H. Kessler La resurrección de Jesucristo, Sígueme, Salamanca, 1989, pp. 44-51). En línea con Kessler, la teología de la liberación ha sido particularmente sensible a comprender la resurrección como justicia para las víctimas. Jon Sobrino no desautoriza que otras teologías otorguen ultimidad a la resurrección de los muertos. Lo interesante de su aporte es que recupera el origen histórico de la fe israelita en la resurrección de los muertos para afirmar que la resurrección cristiana no tendría sentido si no fuera buena noticia en primer lugar para las víctimas (cf. Jon Sobrino Jesucristo Liberador, Trotta, Madrid, 1999, pp. 61-68). La resurrección es para los pobres cosa de justicia tal como lo fue para los Macabeos: "Lo específico de la resurrección de Jesús no es, pues, lo que Dios hace con un cadáver, sino lo que hace con una víctima. La resurrección de Jesús muestra en directo el triunfo de la justicia de Dios, no simplemente su omnipotencia, y se convierte en buena noticia para las víctimas: por una sola vez la justicia ha triunfado sobre la injusticia" (ibidem, p. 130). 
establecer un vínculo entre fe y razón. Y más concretamente, un vínculo entre fe y cultura, y entre fe y ciencia. En el título se ha enunciado que la fe de Jesús constituye la clave de la fe cristiana. Esto es así, sin embargo, solo en la medida que esta fe sea mediada a estos niveles. A este artículo no se le puede pedir más que dejar planteado el tema. Dicho en otros términos, la fe de Jesús y la fe en Cristo constituye la piedra angular de la espiritualidad, de la moral y de la liturgia cristiana toda vez que la Iglesia media esta fe con el auxilio de la razón, en los planos de la cultura y de la ciencia, y como esperanza de justicia y de vida eterna para los pobres antes que para nadie.

En el segundo apartado del artículo se incursiona en "la fe de Jesús" en su Padre. En otro, el tercero, se desarrolla el tema de "la fe del Padre en Jesús". Para ambos casos, el acceso hermenéutico lo facilita el primer apartado, titulado "la fe de la Iglesia".

\section{LA FE DE LA IGLESIA EN JESÚS}

A la fe "de" Jesús se accede a través de la fe de la Iglesia "en" Jesús. La Iglesia que ha experimentado a Jesús resucitado interpreta en esta experiencia su "fe en Cristo". La fe en Jesús constituye la salvaguarda exacta de la unión histórica perfecta entre el Hijo y el Padre. No hay ninguna posibilidad de conocer la "fe de Jesús", dos mil años después de su muerte, que no sea la que nos ofrece la Iglesia que experimentó su resurrección y vive de ella hasta nuestros días.

Es decir, no hay acceso posible a Cristo que no sea histórico y, por tanto, hermenéutico. Los textos bíblicos que nos hablan de Cristo han sido escritos todos sin excepción por discípulos suyos. Y, por otra parte, pueden ser mejor comprendidos por los que hoy los leen en la misma Iglesia que los produjo. Los episodios de la vida de Jesús llegan hasta nosotros por la pluma de los primeros escritores cristianos que, junto con sus comunidades, creyeron que él había resucitado y recuperaron su historia para anunciarlo al mundo entero. No son textos neutrales. Han sido escritos precisamente para despertar y sostener la fe en Cristo. Si se trata de indagar en la humanidad de Jesús, por ejemplo, es en definitiva imposible hacerlo separándola de la humanidad de la Iglesia que nos habló de ella y de nuestra propia humanidad. Sabemos qué significa que Jesús haya llamado a Dios Abba al modo como nos lo cuenta una Iglesia que desde entonces reza el "Padre nuestro". En contrario, es absurdo pensar que se pueda conocer a Cristo saltándose a la Iglesia, a sus hagiógrafos y a los testigos de ayer y de hoy. La Iglesia no es Cristo y Cristo no es la Iglesia, pero pretender separarlos lleva a olvidar exactamente lo que hay que recordar. Esto es, que la fe de la Iglesia "en" Cristo se funde con la fe "de" Jesús, imposibilitándonos conocer esta sin aquella.

Pero hay más. La fe cristiana en sí misma es una realidad histórica: la Iglesia ha creído en Cristo a lo largo de los siglos. La modalidad de la fe cristiana admite innumerables versiones correspondientes a épocas y culturas muy distintas. Es tal la imbricación histórica entre la fe de unos cristianos y otros, que se trasmiten el Evangelio y lo reciben ad modum recipientis, que cualquier intento por fijar el concepto de la fe en las categorías de un tiempo y lugar determinado resulta arbitra- 
rio. La fe, que no puede darse sino inculturada, que en ruptura total con una cultura se hace ininteligible, bien puede verificarse en culturas muy variadas (7).

Bien podría decirse que entre fe, libertad e historia se da una relación triangular necesaria. La fe, antes de plasmarse en un credo (fides quae), constituye una decisión, una opción, un abandono y una obediencia libre a Cristo y al Padre (fides $q u a)$, en respuesta al llamado de Dios a confiar en Él porque en el pasado dio pruebas de confiabilidad y también en el futuro cumplirá su palabra. La historia es inherente a la fe porque la libertad opta por Dios cuando tiene "memoria" culturalmente acumulada de la fidelidad de Dios y porque se orienta por una "promesa" divina que la sostiene, sea para crear un mundo distinto, sea para soportar aquellos sufrimientos que inclinan a pensar que no hay historia sino fatalidad. La fe supone una historia, la experiencia temporal de un Dios que, porque ama, libera al hombre para que, con su creatividad, comience otra vez la historia y la enderece hacia su fin. Sin historia no hay fe. Sin fe no hay historia. En ambos casos la libertad movida por el amor conecta a una con otra, precaviéndolas del pesimismo y de las esclavitudes con que normalmente se conjura el riesgo de la misma libertad.

Tal es el carácter histórico de la fe cristiana que lo que ha salvaguardado el dogma de la Iglesia ha sido la historicidad de Jesucristo. Se critica a la fórmula del concilio de Calcedonia (451) que no da razón de las vicisitudes humanas de Jesús de Nazaret, de su predicación del reino de Dios, etc., pero esta crítica está descaminada porque no pondera lo que entonces estaba en juego y que constituye la garantía ulterior de lo que se exige. A saber, que el Hijo de Dios ha asumido perfectamente la humanidad con todo lo que ella implica, incluida la incertidumbre de avanzar por la vida bajo el régimen del discernimiento de la voluntad de Dios. De aquí que la fe en Cristo es la fe en un ser histórico, no en "algo" imperecedero, sino en "alguien" que ha debido actuar y decidir humanamente, como lo especificó posteriormente el Concilio de Constantinopla III (680). El dogma cristiano ha custodiado la historia de Dios con el hombre que, llegada la plenitud de los tiempos, se tradujo en la prueba máxima de la fidelidad de Dios y la mejor expresión de la fe en Dios de un israelita.

La fe cristiana, por cierto, constituye una realidad antropológica que encuentra paralelos en otras culturas (8). Su concepto puede ser elucidado filosóficamente. El trabajo filosófico por mostrar la razonabilidad de la fe, prepara el terreno para entender la revelación y probar que ella engasta en lo más hondo de nuestra humanidad. Fe y razón, cuando el concepto de ambas respeta su índole específica, cuando compatibilizan en una sola lógica que hace necesaria una para la otra, pueden juntas hacer frente al pesimismo que generan los innumerables males que nos aquejan.

$\mathrm{Y}$, sin embargo, aunque la fe cristiana tenga una estructura racionalmente comprensible y sea posible, por tanto, hallar su semejanza con otros modos de "confiar", ella es única en su especie (9). Que la fe sea fe en Cristo, tipifica y modula el acto

(7) Cf. Ecclesia in America, 16.

(8) Juan Luis Segundo, El hombre de hoy ante Jesús de Nazaret, Tomo I: Fe e ideología, Cristiandad, Madrid, 1982, p. 83.

(9) No hay duda que este asunto constituye una cuestión teológica en sí misma. Para el caso de este artículo puede quedar abierta en el sentido de que, aun tratándose de una fe que solo el Dios trino ha podido desencadenar, ella goza de la racionalidad de la que el Creador ha dotado a todas las criaturas humanas y es, en consecuencia, rastreable filosóficamente. En el otro extremo de lo que 
de creer. En este caso nada puede producir más vértigo que pensar que esta sea fe en un "hombre" que, después de predicar la fe plena en el reino de Dios y de haber sido asesinado por ello, se le cree resucitado y uno con Dios. En otras palabras, lo que la filosofía no captará en un hombre común y corriente, la fe lo proclamará como lo más suyo, no como fe en Dios en general, mas como fe en el Verbo encarnado. La historia judeocristiana es tan interior a la fe, que sin ella no es posible controlar lo que se entiende por fe cristiana. Al margen de la historia de Jesús de Nazaret, la fe antropológica puede configurarse de mil maneras distintas y la fe cristiana podría seguir todos los cursos posibles.

En América Latina se levantan voces en nombre de una fe eminentemente histórica. De la recuperación de los relatos que nos hablan de Jesús de Nazaret depende la fe actual de la Iglesia en un Cristo liberador. En esta clave hermenéutica se defiende una lectura "interesada" de los textos de la Escritura, a modo semejante de la que hicieron los hagiógrafos y comunidades cristianas primitivas por otros motivos también históricos. Los teólogos de la liberación declaran cuál es el motivo actual de su teología como quien pone las cartas sobre la mesa, porque la índole histórica de la fe de la Iglesia exige que los relatos del pasado originen nuevos relatos cristianos liberadores. Por el contrario, el empeño institucional o devoto por restar a la fe de la Iglesia su raigambre histórica constituye para la teología de la liberación una auténtica traición al credo original. Traición preñada de consecuencias nefastas para los pobres.

Dos son fundamentalmente los reclamos de la teología de la liberación sobre el punto. Ya en los primeros años Gustavo Gutiérrez lamentaba el dualismo de una teología incapaz de pensar la acción de Dios en la historia. Gustavo Gutiérrez ha resaltado la importancia de la unidad de la historia en contra de la teología que, por destacar la salvación ultramundana, termina por desvalorizar la historia profana (10). Este planteamiento, sin necesariamente querérselo, perjudica a los pobres. En contrario Gutiérrez reclama que hay una sola historia, la de Dios y la del hombre, en la que es posible distinguir la salvación de Dios como salvación en este mundo y de este mundo. Precisamente esta visión de la historia es la que ha hecho posible concebir la salvación como "liberación".

Por nuestra parte podemos agregar que una Iglesia que encara al mundo como una realidad profana de la que ella, por considerarse sagrada, no forma parte, impide a la misma Iglesia reconocer al Verbo encarnado y la inhabilita, porque la desautoriza para proclamar el Evangelio como auténtica buena noticia. Una Iglesia inconsciente del mundo del que forma parte, que exige del mundo una conversión de la que ella se cree eximida, no puede llevar a Cristo. Si el Hijo de Dios se ha hecho

sería una reducción antropológica de fenómeno, Ebeling subraya la originalidad de la fe cristiana en cuanto tal: “... la foi chrétienne n'est pas une foi particulière, mais la foi en tant que telle. Je condède que c'est là une thèse de dèpart moins évidente. Mais l'histoire du mot 'foi' révèle qu'il ne s'agit pas d'un terme qu'on rencontrerait partout et de façon universelle dans le domaine de la religion; au contraire, ce concept, qui provient de l'Antien Testament, n'a acquis sa signification central et décisive que dans le christianisme. Et la foi chrétienne elle-même, au fond, a toujours voulu être comprise de telle manière que le terme 'croire' trouve en elle sa véritable plénitude" (Gerhard Ebeling, L'essence de la foi chrétienne, Seuil, Paris, 1970, p. 13).

(10) Gustavo Gutiérrez, Teología de la Liberación. Perspectivas, Sígueme, Salamanca, 1990, p. 194. 
hombre para salvar a la humanidad, la Iglesia hace inteligible este misterio no pareciendo más sagrada que profana, sino auscultando en su propia humanidad, en su mundanidad e incluso en su pecado, la acción escatológica del Creador que salva al mundo por amor.

El otro de los reclamos dice relación con las críticas reiteradas que algunos autores han hecho del uso ideológico de la religión y de la teología. La teología de la liberación ha hecho suya la posibilidad moderna de sospechar de la propia Iglesia. Es así que los teólogos de la liberación no solo han confesado sus intereses liberacionistas, sino que han procurado cumplirlos mediante una crítica de la función ideológica que la religiosidad latinoamericana y la institucionalidad eclesiástica han jugado en contra de los pobres. Jon Sobrino reprocha a la Iglesia latinoamericana haber predicado a un "Cristo sin Jesús", que sería la fragua de una serie de imágenes alienantes de Jesucristo (11). Se dirá, no sin algo de razón, que es esta una mirada sociológica reduccionista de la Iglesia, que olvida el respeto que merece su carácter sobrenatural. Pero una vez que se ha recuperado la índole histórica de la Iglesia -como arriba se ha dicho- se ha hecho inevitable analizar sus relaciones con las otras instituciones y fuerzas sociales, y evaluar su contribución a la liberación de los pobres o a su sometimiento. En este sentido la sacralidad de Iglesia ya no podrá nunca más blindarla a las críticas seculares. La liberación de los pobres, en este caso, hace las veces de criterio clave de la verificación de la salvación, y podríamos agregar, de la santidad cristiana. Y, a propósito del acceso a Jesús buscado, la "Iglesia de los pobres" contribuye a esta liberación y, mediante la repetición de la praxis liberadora de Jesús de Nazaret, al conocimiento del mismo Jesús. Los pobres tienen un modo particular de creer que enriquece la comprensión de Cristo de la Iglesia. Afirma Sobrino: "Por ser los privilegiados de Dios y por la diferencia con la fe de los no pobres, los pobres cuestionan dentro de la comunidad la fe cristológica y le ofrecen su dirección fundamental" (12).

De la otra parte del mundo, Aloysious Pieris confirma la importancia que tiene la eclesiología para la cristología. En Asia, un continente en que los cristianos suman solo un 3\% de la población, el teólogo cingalés posterga el desarrollo de una cristología asiática hasta que no haya allí una Iglesia pobre y auténticamente asiática (13).

En fin, no cualquier modo de creer de los cristianos constituye un principio de acceso a Jesucristo. Hay realizaciones eclesiales que derechamente lo impiden. En la perspectiva de la justicia debida a los pobres y las víctimas del pecado o de un sufrimiento que hunde sus raíces en el más oscuro de los misterios, la Iglesia

(11) Jon Sobrino, Jesucristo liberador, Trotta, Madrid, 1991, pp. 29-32.

(12) Ibidem, p. 50

(13) Dice Pieris: "La primera fórmula cristológica relevante -que sería a la vez homóloga y kerygmática, es decir, que tendría sentido para cristianos y no cristianos- es una Iglesia auténticamente asiática, lo cual, por supuesto, dista mucho de la comunidad esotérica que es hoy, una comunidad que grita en el oculto lenguaje de los fundadores coloniales y es entendida solo por los iniciados. Para salir de esta situación de confinamiento debe tomarse tiempo para entrar en las aguas bautismales de la religiosidad de Asia y pasar por la pasión y muerte de cruz de la pobreza de este continente. Mientras no se consume esta revolución eclesiológica, no habrá una cristología asiática" (Aloysius Pieris, "Hablar del Hijo de Dios en las culturas no cristianas de Asia", Concilium 173 (1982), p. 396) 
contribuye a su liberación, no aporta nada o suma su influjo al de los poderosos que los oprimen.

\section{LA FE DE JESÚS EN DIOS}

\section{a) De la fe antropológica a la fe teológica}

La pregunta por qué la Iglesia creyó que Jesús era el Hijo, esconde otra aún más fundamental: ¿por qué la Iglesia creyó en un "hombre"? Creer en Dios es lo propio de la fe religiosa. Creer en un hombre es posible en términos muy limitados. Por tanto, que un hombre merezca fe religiosa es, en principio, demencial. La Iglesia no ha podido ser más audaz al poner las cosas al límite de la racionalidad, cuando ha proclamado su fe en un hombre que, como todo hombre, es incapaz de asegurar por sí mismo el cumplimiento de su palabra. Porque, ¿cómo puede responder por sus promesas alguien que no puede responder por su vida? La muerte se lo lleva todo.

Pero hay todavía otra pregunta que lleva las cosas al extremo: ¿por qué la Iglesia creyó en un "crucificado"? No en un muerto más, sino en un condenado a muerte. Afirmar que, en realidad, ha creído en un resucitado elude algo decisivo. Porque la fe en el resucitado solo tiene sentido para la Iglesia cuando se afirma su identidad con el crucificado. Desde un punto de vista filosófico la pregunta por la resurrección excede el campo antropológico y, si algo se puede indagar de ella, solo en el hecho de la muerte de Jesús en cruz puede encontrar algún pie de apoyo, y siempre que la fe en un crucificado tenga alguna racionalidad.

Fe en un hombre

La fe en el hombre Jesús supone como condición indispensable que sea posible creer "en" un hombre. Sin mordiente antropológica la fe en Jesús carecería de sentido. Y como todo lo que filosóficamente carece de sentido, si se lo levanta como paradigma de lo humano, lleva a las penosas consecuencias que se siguen de cualquier apuesta por la irracionalidad. En otras palabras, la "fe humana" -por llamarla de algún modo- ilumina la credibilidad de Jesús. Sin ella, la fe religiosa en Jesús es ininteligible, pero no inocua.

La credibilidad humana, a su vez, se articula bajo dos respectos íntimamente vinculados. Los hombres creemos en "algo" y también creemos a "alguien". Ninguno de nosotros podría comprobar por sí mismo que la inmensa mayoría de saberes sobre los que descansa la vida es verdadera o falsa. Son muy pocas las cosas sobre las cuales podemos decir que tenemos una comprobación personal. Todos nosotros descansamos sobre los conocimientos milenarios, las ideas, la sabiduría que la humanidad ha adquirido fatigosamente por sucesivas generaciones para elevar sus condiciones de vida. Por lo demás, si la verdad tiene una dimensión histórica en el amplio campo de aquello que no es apodíctico, ocurre que ese "algo" que creemos verdadero es susceptible de verificación. El conocimiento se incrementa por la superación de la ignorancia o el error. De aquí que sea aún más complejo pensar que 
cada uno de nosotros sabe "algo" por sí mismo. Si "algo" sabe, en otras palabras, si tiene la verdad, la tiene en la medida que la historicidad de la humanidad se lo concede. Por tanto -siempre en el plano filosófico-, no podemos otorgar a la enseñanza de Jesús un grado de verdad que no cumpla con estas características. Pretenderlo, en realidad, nos pone del lado del engaño voluntario o incauto, lo que es especialmente grave cuando se avalan estos procedimientos en el nombre de Dios. "Algo" sabemos, sin duda, aunque sea nuestra propia ignorancia. Sabemos que ignoramos, pero también que podemos aprender. La sensatez humana fundamental nos permite "creer" en la verdad aunque sea con esta precariedad suya, la cual, paradójicamente, constituye una riqueza en cuanto cura de la hybris del conocimiento y de las mejores ideas de la humanidad.

Pero, en definitiva, la fe antropológica en "algo" descansa en la fe en "alguien". Necesitamos confiar en personas. No nos basta con estar en la verdad (distinta del error), pues la humanidad requiere ante todo una articulación moral, una verdad moral o personalmente sustentable (distinta de la mentira). "Alguien" nos puede engañar sin quererlo. Ha sucedido y seguirá ocurriendo, en el sentido antes dicho: pasamos continuamente de la ignorancia al conocimiento. Por cierto, la falta de verdad en este plano tiene consecuencias negativas. Pero la falta de verdad moral tiene un efecto devastador para las relaciones de las que depende la felicidad humana. Una sociedad insegura, desde este punto de vista, es una sociedad en peligro de desintegración. Incluso las agrupaciones mafiosas prosperan en base a férreos códigos de honor. Se podrá decir que también otros factores pueden amenazar la convivencia humana, y no solo aquellos en que no se puede confiar en los demás. Las pestes diezmaron la población europea. Otras enfermedades hicieron algo parecido con las etnias latinoamericanas. Pero, en búsqueda del tipo de verdad que el hombre Jesús representa, si "algo" dice él de Dios vale en tanto Jesús es "alguien" que merece fe humana. En otras palabras, en la persona de Jesús, en su condición de hombre veraz y no por otro título, descansa la veracidad de su enseñanza sobre Dios. Que él sea el Hijo de Dios y que por esta razón merezca ser creído, no tendría el más mínimo valor si los que así lo confesaran no aceptaran la radicalidad de su historicidad, su discernimiento de la voz del Espíritu con los criterios de sus antepasados acerca de "qué" y "quién" es Dios para su pueblo.

Desde un punto de vista antropológico, es admisible que Dios represente ese "algo" que, en última instancia, es "alguien" que cumple su palabra. "Dios" puede ser la cifra de la "fidelidad personal" (aquella piedra angular de la convivencia humana). Y, también en perspectiva filosófica, Jesús, como "Palabra de Dios", puede simbolizar la idea reguladora de una verdad que se cumplirá en el futuro en la medida que los hombres, en el presente y confiados en la veracidad de sus testigos, se comprometan unos con otros en el camino de la vida y respalden sus palabras con sus cuerpos. Por otra parte, no es filosóficamente admisible que la fe en Dios sea conocimiento sin ser fe en sentido estricto; que se crea que Dios es así o asá, sin creerle primariamente a Él en cuanto sujeto de crédito y de obediencia. Tampoco podría tener valor antropológico que la Iglesia pretenda conservar la fe "en" Jesús sin necesidad de recuperar la fe "de" Jesús. Tal pretensión tendría evidentes visos de inhumanidad. Entre la fe en Dios ("alguien") y el credo de la Iglesia ("algo"), la fe antropológica y teológica de Jesús constituye la bisagra fundamental. 
La figura de Jesús como hipótesis de la perfección de la fidelidad humana, falla en la medida que hacemos de ella meramente "algo" desprovisto de interioridad. En virtud de la Encarnación del Hijo descubrimos que la palabra humana tiene valor de Palabra divina. La razón exige que así sea, de lo contrario la historia carecería de consistencia y la fidelidad humana no tendría importancia alguna. ¿Qué sentido pudiera tener creer a Dios si no creemos a los hombres? Ello nos sacaría de la vida. Nos llevaría incluso a desconfiar de los demás. Sin embargo, la racionalidad de la fe en Dios tropieza cuando imaginamos que podemos calcular o regir la actuación humana a partir de un código hipotético, al modo de una norma ética que, por ejemplo, ha de aplicarse sin más, sin necesidad de interpretación y discernimiento. El racionalismo, en el plano teológico, capta la forma de la Encarnación (la identificación de Dios con el hombre), pero vacía su contenido (el amor inconmensurable de Dios por el hombre). Por el contrario, la ortodoxia señala que en el Hijo encarnado recuperamos la racionalidad de la historia, pero corregimos la tendencia a medir la fidelidad divina con la vara de la fidelidad humana. En Jesús hallamos también, y sobre todo, la novedad de la fidelidad de Dios con un hombre finito e incapaz de cumplir por sí solo sus promesas.

La fe en Cristo engasta en la fe humana de Jesús. Esta le otorga inteligibilidad. Le evita el curso del fideísmo. Pero, por otra parte, la revelación de la fidelidad de Dios en Jesús nos habla de una fidelidad que no es de este mundo, de un amor que excede los cálculos de la fidelidad humana. El racionalismo teológico en esta materia, hacer de Jesús la cifra racional de la fidelidad humana, lleva a exigir fidelidades que pueden ser tan extremas como inhumanas. En última instancia solo Dios puede exigir al hombre fe total. Pero no simplemente el Dios de la razón, sino el Padre amoroso de Jesucristo.

Fe en un crucificado

La fe de la Iglesia en el hombre Jesús -principio de inserción y de corrección de la fe de la Iglesia en el Hijo de Dios-, alcanza su máxima radicalidad cuando nos exige creer en un crucificado. Por tanto cabe también preguntarse hasta dónde sea humanamente posible creer en un crucificado.

En la perspectiva de los triunfadores, esta es, en la óptica de aquellos que apuestan a ganar a los demás, creer en un crucificado constituye el absurdo en sí mismo. Pero no hay que pasar muy rápido sobre este hecho. Se trata de la lógica que regula el mundo con una fuerza casi incontrastable. Nadie se sustrae completamente a ella. No es necesario llamarla "pecado" para percatarse de sus efectos devastadores. También los no creyentes la reconocen y son sus víctimas. Tal es el poder de la lógica del triunfo de los ganadores, que ella exige de la conciencia colectiva un reconocimiento exclusivo. Esta es la lógica, no hay otra. Ningún ejemplo la caracteriza mejor que el del capitalismo, con sus promesas de progreso y su concentración de la riqueza.

He aquí otro motivo para sospechar de la mera fe antropológica. El capitalismo funciona sobre la base de la confianza. Si no fuera posible creer en los demás, sin canales jurídicos que encaucen los negocios y los contratos como lo hacen los códigos civiles, el mercado no podría asignar adecuadamente los recursos. El capita- 
lismo reclama confianza como condición de racionalidad sine qua non de las operaciones comerciales. Cuando además recibe una sanción teológica, es capaz de casi todo. Solo sus "crucificados" pueden enfrentarlo.

Lo pueden, porque también es un dato antropológico que los "crucificados" tienen una razón de ser. Los vencedores dirán que esta se reduce a hacer funcionar el sistema, lo que equivale a negarles su razón personal de ser. La razón de ser de los "crucificados", empero, no es teológica. La ética se sostiene en sus propios pies. La fundamentación religiosa de la ética no excluye que, racionalmente, podamos concluir que los pobres tienen una lógica que puede ser reconocida por pobres y ricos, poderosos e impotentes. La fundamentación religiosa tampoco está exenta, ya se ha visto, de argumentar racionalmente. Más aún, está obligada a asumir la razón de ser del dolor de las víctimas si quiere ser absuelta en el tribunal de la historia.

Las víctimas, los perdedores y los ajusticiados injustamente tienen una razón de ser aunque solo se evidencie como un grito contra la injusticia. En última instancia, de este grito depende que el hombre no pueda ser reducido a "algo". La humanidad depende del grito de "alguien". Alguien que reclama por el predominio de la lógica interpersonal sobre la lógica de los sistemas y subsistemas que, no por ser impersonales son innecesarios, pero que de suyo no saben hacia dónde conducir a la humanidad porque carecen de libertad.

El grito de Jesús es el grito de "alguien" en contra de pragmatismos tan sensatos y eficaces como el de Caifás que aconsejaba eliminar a uno por el bien de la nación (14). El cristianismo no es cristianismo si no acoge el grito histórico de los excluidos o eliminados por razones superiores. El grito de Jesús representa el grito de la humanidad contra la lógica implacable de los sistemas, las instituciones y las cosas que amenaza y destruye personas, su dignidad y su libertad.

El grito de Jesús es único porque en la cruz Jesús, en contra de la lógica de la justicia mecánica, perdona incondicional y gratuitamente. Pero esto, que solo un hombre como Jesús ha podido realizar, halla su racionalidad en la solidaridad del crucificado con las víctimas inocentes que antes y después lo han tenido a él como el representante de su grito inocente. Hay también otra lógica, la de las víctimas. Sin ella, la lógica del empeño, de la eficiencia y del triunfo de la humanidad sobre su finitud galopa sin freno sobre los cadáveres. La resurrección de Jesús, si alguna lógica puede tener un dato teológico, no puede sino constituir la confirmación de que Jesús no creyó en Dios en vano, es decir, que su grito de hombre y de víctima fue escuchado. Y que la realidad, si alguna racionalidad tiene, es mejor conocida a partir de los pobres.

Porque la otra alternativa, exactamente la contraria, es la del fideísmo. El peligro que acosa a todas las prisas por exaltar el valor de la cruz de Jesús, consiste en restar simplemente valor a la pasión humana tanto por elevar las condiciones de vida como por soportar las injusticias de esta empresa. La cruz del hombre Jesús no tiene ningún valor independientemente de la pasión de la humanidad. Sin perjuicio de su gratuidad, la cruz del Hijo de Dios carecería por completo de sentido si a través de ella se

(14) Las palabras en boca de Jesús al momento de su agonía y muerte son inmediatamente precedidas por un grito dirigido a Dios que, a semejanza de los descargos de Job, también puede considerarse un modo de oración (cf. Mc 15, 34; Mt 27, 46; Lc 23, 46). 
consiguiera una salvación que no fuera liberación intrahistórica del pecado y, al mismo tiempo, comienzo nuevo del empeño humano por una vida mejor.

Pero el fideísmo niega indistintamente valor tanto a la racionalidad humana como al reclamo de las víctimas. La cruz en este sentido se eleva como un misterio de salvación por sí mismo. Al modo de los anselmianismos, el fideísmo acaba por restar importancia a la predicación de Jesús de un reino de Dios a los pobres, para otorgársela exclusivamente a un hombre que, por ser divino, ha podido morir para merecer por los demás (15). La salvación no es solo redención del pecado. Es también plenitud de una creación que solo la creatividad humana, purificada de su hybris, puede alcanzar. El fideísmo, en definitiva, opone a la lógica racional la lógica de la fe escondida en la cruz de Cristo como un misterio tan impenetrable que la pasión de las víctimas no puede siquiera ser llamada injusta. Y, como todo puritanismo, el fideísmo deja que la historia siga indiferente su curso, sin preocuparse de las mediaciones racionales que en alguna medida pueden achicar el dolor y la injusticia que padecen los pobres. Una fe tan pura conspira contra la suerte de los pobres con una insensibilidad parecida a la del racionalismo que les ofrece un progreso futuro a costa de un presente miserable.

\section{b) La fe en virtud de la misión e identidad del Hijo}

La fe en el hombre, la fe antropológica, es necesaria para mediar la acción creadora de Dios. Pero si la fe en el hombre es simplemente identificada con la fe en Dios, el hombre padecerá las consecuencias. Juan Pablo II denunciaba esta posibilidad al inicio de su pontificado, recordándonos que la obra del hombre se había vuelto contra el mismo hombre (Redentor Hominis, 15-16). La fe en los crucificados, aunque también constituye una modalidad de fe antropológica, rescata la razón de ser de aquellos que han sido despojados de su valer personal. Y, sin embargo, ella tampoco es suficiente. También ella puede deformar al hombre. La fe antropológica que afirma que los crucificados alguna razón tienen, que merecen justicia, corre el riesgo de mistificar a las víctimas y, por otra parte, puede sabotear los esfuerzos racionales por sacarlas de su condición. La protesta contra la injusticia no basta para superarla. Se entiende que a veces las obras de la razón no logran sustentar la fe en el hombre. Pero si la fe de los crucificados no coopera con la acción racional que procura liberarlos de la cruz, puede conducir al fideísmo que promete a las víctimas una justicia para la otra vida, pero no para esta.

Esta dialéctica es inherente al misterio de Cristo. Su reino es y no es de este mundo. La exégesis descubre rasgos apocalípticos en la personalidad de Jesús, pero también la recomendación de Jesús de un modo de organizar la convivencia humana como si la historia aún no fuera a acabarse.

Desde un punto de vista histórico y especulativo, es posible descubrir que la cristología oscila entre la identidad personal de Jesús y su misión escatológica de mediador del reino. El reino de Dios es la única respuesta racional a la demanda de

(15) Cf. González-Faus La humanidad nueva. Ensayo de cristología, Sal Terrae, Bilbao, 1984, pp. 481-489. 
los crucificados, pero en última instancia este reino consiste en creer en el hombre crucificado que creyó en el Dios del reino y por eso fue resucitado. A saber, el Hijo de Dios encarnado, la cura precisa del racionalismo y del fideísmo.

Las razones de Jesús para no creer

La misión de Jesús consistente en el reino de Dios, nos revela su identidad y su interioridad. Y, viceversa, el acceso a su interioridad e identidad -posible en virtud de las huellas evangélicas y de la experiencia espiritual de la Iglesia- nos permite comprender mejor el reino que constituye la misión de Jesús.

El caso es que la misión de Jesús sería para nosotros ininteligible si no se tuviera en cuenta lo dicho arriba acerca de la dimensión antropológica de la fe y, en concreto, si no se indagara en las razones que el hombre Jesús ha podido tener para "no creer" en Dios. La misión, en sentido estricto, es el envío que el Padre hace de su Hijo a liberar, en primer lugar, a quienes más necesitan de Dios; a aquellos que solo en Dios podrían confiar, pero que en lo inmediato tienen razones para pensar que Dios los ha abandonado, porque tampoco Él ha intervenido cuando ellos no han podido ya confiar en nada ni en nadie. Si la misión de Jesús resuena interiormente en él como una respuesta del Padre a una necesidad propia suya y apropiada por Jesús solidariamente -condición antropológica de una Encarnación coherente con el concilio de Calcedonia-, cabe preguntarse: ¿cuáles han sido las razones de Jesús para "no creer"? Pues bien, las razones para no creer del salvador escatológico han de ser las mismas de su propio pueblo (que, a la vez, representa las razones de todos los pueblos de la tierra). Sería un anacronismo pensar que los israelitas de entonces oscilaban entre el ateísmo y la fe en Dios. El ateísmo es un fenómeno moderno. Pero la desconfianza en Dios es antigua y se recicla.

Conviene hacer algo de historia. En tiempos de Jesús la confianza en Dios se había debilitado. Se había fortalecido, en cambio, la ilusión de que algún poder se impusiera a quienes oprimían a Israel. Los romanos predominaban en toda la región. Se afirmaba la causa revolucionaria de los zelotas. Y además de las opresiones y miserias sociales, las mayorías ignorantes debían soportar las interpretaciones farisaicas de la Torá y los impuestos de los sacerdotes del Templo que agobiaban sus vidas. Estas razones para "no creer" en Dios, ha debido llevarlas Jesús en el corazón: la desesperanza, la humillación, la vergüenza y el dolor de Israel, la tragedia de los pobres, sus enfermedades, sus estigmas, sus traumas y en particular el hado de los inocentes del abuso del poder político y religioso. El mal del mundo que ha acompañado a la humanidad desde siempre, su capacidad para oscurecer el horizonte, atormentó a Israel y ha debido atormentar también a Jesús. Jesús -por decirlo así- representó a Israel en la batalla contra el sufrimiento de su época, padeciendo interiormente la fuerza amenazadora de los poderosos y resistiendo esta capacidad del mal de aterrar a los impotentes y enrolarlos otra vez en el encubrimiento del daño que ellos mismos padecen. Han debido ser estas razones para no creer de Jesús, ni en los hombres ni en Dios, las que nutrieron las tentaciones de que nos habla el Nuevo Testamento.

Así Jesús ha podido adquirir la representatividad para anunciar el reino de Dios: en nombre de los abandonados, de los huérfanos de Dios, no de otro modo; 
queriendo ser pastor de un pueblo que merecía misericordia porque parecía no tener pastor que lo cuidara y lo condujera. Jesús despertó las expectativas mesiánicas de Israel y facilitó el reconocimiento como Mesías de los discípulos después de su muerte, haciendo suya la suerte de los pobres hasta las últimas consecuencias. La estrecha solidaridad de Jesús con las víctimas inocentes, no algún título "divino", ha podido acreditarlo para animar a los israelitas a no desesperar de Dios.

Los evangelios han caracterizado a Jesús por su "autoridad". A diferencia de los maestros de la Ley y fariseos que enseñaban al pueblo pero sin hacer suya la real necesidad del pueblo de ser enseñado, Jesús lo hizo con autenticidad. El enseñó como alguien que comparte el desgarro de un sufrimiento que parecía no tener fin, lo hizo misericordiosamente y bebiendo el cáliz de ese padecer que hace que el ser humano se rebele contra las explicaciones racionales del mal y los predicadores dispuestos a salvar la doctrina antes que a las personas. A Jesús la autoridad se la reconocieron las víctimas de una sociedad injusta e insensible. No las autoridades religiosas de Israel y tampoco el procurador romano. Los sacerdotes, a los que disputó esta autoridad, lo eliminaron.

La autoridad de Hijo propia de Jesús la reconoció la Iglesia naciente, a quien vio morir gritando "Dios mío por qué me has abandonado". A Jesús, desautorizado en la cruz, "huérfano" entre los huérfanos de Dios, la Iglesia, que con la resurrección experimentó la salvación como fraternidad, lo confesó como "Hijo" (16). Si la autoridad le fue dada a Jesús de lo alto en virtud de su filiación divina, ella no se manifestó en su tiempo como un poder extra para impermeabilizarse a las debilidades de la carne e imponerse a los demás en virtud de una supuesta omnipotencia y omnisciencia. Una tal autoridad lo habría inhabilitado para representar a los que tenían razones para no creer. Y, peor aún, habría convertido a Jesús en otra amenaza más a su libertad.

Los discípulos que sabían de orfandad y que vieron a Jesús abandonado del Padre, una vez que fue rehabilitado por Él y habiendo ellos mismos experimentado al resucitado como filiación y fraternidad, reconocieron su identidad de Hijo y la autoridad que en nombre de su Padre tenía. También le llamaron Señor, pero no por predominar sobre los demás con majestuosidad divina, sino por hacerlo como siervo humilde de Dios y de los hombres.

Las razones de Jesús para creer

El reino de Dios anunciado a los pobres, la misión de Jesús, ha tenido un fundamento interior. A saber, el amor de Dios por los pobres experimentado por Jesús como amor filial por él mismo. Jesús es el Hijo, y también podríamos llamarlo “el Pobre” (2 Cor 8, 9; Fil 2, 7-8). No es posible separar en Jesús misión e identidad

(16) Los estudios bíblicos aportan un dato importante. Probablemente el Jesús prepascual no se llamó a sí mismo "Hijo" o "el Hijo". Jesús, consciente de su unidad filial con su Padre, no quiso, sin embargo, distinguirse de los demás por una especie de privilegio divino. Pero la comunidad cristiana naciente lo llamó explícitamente "Hijo". Lo hizo para reconocer la identidad más profunda de Jesús. Y para salvaguardar una salvación que ellos experimentaron como hijos e hijas de Dios, hermanos unos con otros en razón del mismo Padre al que Jesús les había enseñado a referirse como "Padre nuestro" (Adolphe Gesché Jesucristo, Sígueme, Salamanca, 2002, p. 215). 
sin llevar las cosas a extremos espirituales y morales perniciosos. El acento unilateral de la cristología en la persona de Jesús, con olvido de su proyecto histórico, conduce al intimismo y al fideísmo que se desentienden de la salvación del mundo que sufre. Por el contrario, la preocupación de la cristología por destacar la importancia soteriológica del reinado de Dios en favor de las víctimas de una sociedad injusta, cuando ha ido aparejada de una desatención a la persona del Hijo y del talante personal de la salvación, ha llevado a traducir el cristianismo en un "socialismo" y en un racionalismo deshumanizante también para los pobres (17).

Jesús tuvo razones para "no creer". Fue autorizado para anunciar el reino de Dios como fundamento de la fe al hacer suyas las razones de su pueblo para desconfiar de Dios "impotente" ante sus males (cf. Hb 4, 15 y 5, 7-10). Por haber creído Jesús en su Padre a pesar del fracaso de su nación y venciendo las tentaciones mesiánicas, pudo anunciar el Evangelio con autoridad. Porque padeció el pecado hasta su consecuencia última de muerte, Jesús pudo anunciar a Israel una "buena noticia" y constituirse él mismo en la mejor de las noticias de parte de Dios. Así la salvación, amén de respetuosa con sus beneficiarios, exenta de paternalismos, ha sido efectiva y en definitiva se ha jugado en un encuentro entre personas, esto es, con Jesús y entre los hombres.

Jesús tuvo las mismas razones de su pueblo para no creer, pero creyó y no pudo ser de otro modo. Independientemente de los resultados de la exégesis, que parece inclinarse a interpretar los textos polémicos en la línea de una fe subjetiva de Jesús, las indicaciones dogmáticas de los concilios ecuménicos de Calcedonia, Constantinopla II y Constantinopla III nos orientan en esta dirección (18). La teología del siglo XX lo afirma prácticamente con unanimidad (19). Por cierto adentrarse en el alma de Jesús, además de carecerse de datos objetivos suficientes, no podrá nunca hacerse sin reconocer que se trata del misterio por excelencia. Sin embargo, dentro de estos límites es posible inferir que Jesús ha sido el creyente por antonomasia. Si no fuera posible hablar de la interioridad de Jesús ni siquiera de un modo hipotético -modalidad que aquí asumimos-, adoleceríamos de una suerte de apolinarismo. Jesús no es una especie de marioneta del Logos. De acuerdo al principio de

(17) En la discusión latinoamericana del tema encontramos dos posiciones opuestas, aunque ambas legítimas, en los casos de Jon Sobrino ("Mesías y mesianismo. Reflexiones desde El Salvador," Concilium, 245 (1993) 159-170) y Antonio González ("El anuncio del reinado de Jesús, el Mesías", en Comisión Teológica de la Compañía de Jesús en América Latina, Jesucristo, prototipo de humanidad en América Latina, Tercera Reunión, Obra Nacional de la Buena Prensa, Ciudad de México, 2000,pp. 129-158).

(18) Manuel Gesteira en un artículo reciente titulado "La fe-fidelidad de Jesús, clave central de la cristología", abunda en argumentos exegéticos que prueban que Jesús tuvo fe subjetiva en Dios. En San Pablo, la fe de los creyentes en Jesús depende de la "fe de Jesús". De otro modo la justificación por la fe constituiría obra humana. El texto clave aducido por Gesteira es Rom 3, 2122: "Mas ahora, sin la ley, se ha manifestado la justicia (dikaiosyne) de Dios, atestiguada por la ley y los profetas: la justicia de Dios por (medio de) la fe de Jesucristo (dia pisteos Iesou Christou), para todos los que creen, sin distinción". Como coronación de los varios versos evangélicos que afirman algo parecido, Gesteira recuerda que el autor de la Carta a los Hebreos destaca que Jesús es el creyente por antonomasia. Él es el "autor (precursor) y consumador de la fe" (ton tes pisteos archegon kai teleioten)" (Heb 12, 2). Sin su fe, la fe de los cristianos sería imposible.

(19) Cf. supra, nota 1. 
los padres según el cual "lo no asumido no es salvado", grave sería callar sobre el alma de Cristo porque equivaldría a renunciar a la espiritualidad cristiana. Es preciso incursionar en su interioridad aunque sea al modo de la teología negativa (20). Pues si no recuperamos la interioridad de Jesús, su orientación "espiritual" al Padre -esto es, de acuerdo al Espíritu Santo-, nos convertiríamos en esclavos de sus palabras y acciones, en repetidores y no seguidores suyos dotados del don espiritual de la fe e intérpretes de su voz.

Se ha dicho que en virtud de la "visión beatífica" que Jesús ha tenido de Dios en el curso de su vida terrena, él no habría tenido fe, sino conocimiento perfecto de Dios, de sí mismo y de su misión (21). Autores como K. Rahner han preferido hablar de "visión inmediata" del Padre para articular este conocimiento que Jesús no ha podido no tener, y a lo largo de toda su vida, con la índole histórica del progreso del aprendizaje humano (22). En este artículo no se ha querido entrar de lleno en esta discusión. Aquí basta con tener presentes los límites dentro de los cuales es posible explicar este asunto. Estos son, que Jesús llegó a saber de un modo progresivo lo que él conoció de un modo absoluto desde el momento de la Encarnación: todo lo necesario para nuestra salvación. Lo que no puede discutirse es que la Encarnación se verifica en una auténtica kenosis; que la humanidad plena del Hijo es condición de posibilidad de una salvación que excluye radicalmente el extrincesismo que reciclaría el régimen de esclavitud religiosa del que Jesús quiso liberarnos.

¿Tuvo Jesús razones para creer en Dios? Sí, Dios mismo. No cualquier Dios, por cierto, sino aquel Padre que toma en serio las razones del Hijo para "no creer". Pero Jesús no ha tenido propiamente "razones" para creer en su Padre, sino una experiencia de su Padre en el Espíritu. Su fe constituye la experiencia espiritual de Dios por excelencia. Él se ha convertido en nuestro camino, porque él hizo el camino bajo la guía del Espíritu de amor y de discernimiento. En realidad nadie ha tenido más fe que Jesús. Esta experiencia de Dios, sin embargo, para ser plenamente humana -como en su caso lo es más que en nadie- ha debido también ser racional.

Esto es lo que es necesario indagar, pues de la articulación entre razón y fe depende estrictamente la vida espiritual de los cristianos. Esta depende de la vida espiritual de Jesús. Si esta nos fuera irrecuperable, si la recuperáramos con perjuicio de la racionalidad de su proyecto histórico, nos quedaríamos con un Jesús "no

(20) Conviene recordar el recurso de Calcedonia a adverbios negativos para hablar de misterio de la unión en la persona del Hijo de su naturaleza humana y su naturaleza divina, al decir que esta ocurre "sin mezcla ni confusión, sin división ni separación" (DH 301-302).

(21) Un decreto del Santo Oficio, de 1918, defiende la doctrina de la visión beatífica y el conocimiento universal infuso de Jesucristo (DS 3645-47). A estos, hay que añadir un texto de Mystici Corporis (DH 3812) en favor la visión beatífica. Pero en ninguno de estos casos, según Bernard Sesboüé, existió la intención de definir nada. De hecho, los otros dos documentos importantes que se refieren específicamente al asunto de la conciencia de Jesús - "Biblia y cristología", de la Comisión Bíblica Pontificia" del año 1984, y "La conciencia que Jesús tenía de él mismo y de su misión" de la Comisión Teológica Internacional de 1985-, no vuelven a mencionar la "visión beatífica" del Jesús prepascual, en cambio sí hablan de un progreso de su conciencia (cf. B. Sesboüé, Pédagogie du Christ. Eléments de christologie fondamentale, Cerf, Paris, 1996).

(22) Karl Rahner "Considérations dogmatiques sur la psychologie du Christ", Exégèse et dogmatique, Paris, DDB, 1966, 185-210; 
cristiano". Sin embargo, a la fe de Jesús accedemos indirectamente a través de las huellas evangélicas y eclesiales que la razón puede rastrear con la ayuda del mismo Espíritu que en ese tiempo hizo que Jesús creyera. De esta forma podemos hallar la estructura racional precisa de esta fe sin la cual no sería posible precaver al cristianismo de la irracionalidad o del racionalismo.

Solo así entendemos que Jesús ha tenido una gran razón para creer: la experiencia del amor de su Padre. Los cristianos, participantes en el misterio del Hijo, rastrearon este dato fundamental de la revelación en la experiencia que ellos mismos tuvieron de Dios: "Nosotros hemos sabido el amor que Dios nos tiene y hemos creído en Él" (1 Jn 4, 16). Para que este fundamento no apoye el fundamentalismo que suele vaciar a los conceptos de su origen histórico, la dedicación de Jesús a proclamar el reino de Dios a los pobres (las víctimas del sufrimiento y del pecado) y a los pecadores (causantes del sufrimiento ajeno) indica que Jesús entiende que el amor de Dios es misericordioso y gratuito: ni pobres ni pecadores pueden dar nada equivalente a cambio de su salvación.

Apoyados en las señales del Nuevo Testamento, particularmente de San Pablo, podemos inferir que el mismo Jesús ha experimentado el amor gratuito de Dios por él como la fuente próxima de su extraordinaria libertad y creatividad, de su capacidad para amar a los que nadie ama, para vencer el miedo que amilana a los débiles, para padecer la fidelidad a su vocación y para soportar la cruz. Nuevamente se hace difícil decir una palabra acerca de cómo se articulan estos aspectos humanos en la interioridad de la persona divina del Hijo. Pero, aunque solo sea de un modo superficial, podemos imaginar que la libertad de Jesús, que bajo otro respecto hemos llamado "autoridad", proviene de un amor que lo obliga a responder con amor a un Padre que le merece confianza total. Y, por el contrario, si el hombre de Nazaret hubiera dudado de este amor, si hubiera tenido miedo a Dios, a su reacción o su castigo, difícilmente habría creído en Él y, en consecuencia, probablemente habría buscado otras seguridades para salir adelante. ¿No es la falta de fe en el amor de Dios, el miedo de no contar con Él, lo que hace que los hombres se aprovechen unos de otros?

Las palabras de Jesús: "No tengan miedo" son equivalentes a estas otras suyas: "Tengan fe". Esta es su experiencia. Porque él sabe que su Padre que lo ama lo sacará adelante aunque él no entienda exactamente cómo, porque no tiene la más mínima duda del amor de Dios, Jesús puede llegar a no temer a nadie ni a nada. Así, desenvolviéndose con libertad y arrojo, seguro en su Padre, contagia a los demás aquella valentía sin la cual no se descubre la propia identidad y misión. Por esta vía es posible adentrarse, además, en los meandros de la inocencia radical de Cristo. Esta no ha podido ser automática. La unión perfecta de Jesús con su Padre en virtud del amor del Espíritu, excluye en él el miedo al futuro que normalmente lleva a controlar la incertidumbre de la vida, los terrores del porvenir, manipulando cosas y personas. Jesús, sin temor a ese futuro que todo hombre ignora, revela qué es lo humano. El pecado deshumaniza. Solo el amor humaniza. Por Jesús sabemos que el amor desencadena la fe en el amor y que, por el contrario, no puede haber fe, y no puede haber humanidad plena, allí donde el amor es precario o intercambista. La falta de fe conduce al pecado. La fe, en cambio, inicia en el hombre el proceso de humanización en virtud de un amor libre de temor y fundamentalmente creativo. 
El mal del mundo hace difícil creer en la bondad de Dios. El hombre que no cree en Dios porque no sabe que Dios lo ama como amó a Jesús, suele colaborar al mysterium iniquitatis. Una de estas modalidades consiste en aferrarse a un Cristo que desprecia el mundo sin más. La historia de Jesús, sin embargo, nos habla de un modo creativo de salir al paso del sufrimiento del mundo. Esta creatividad tiene el mismo origen que su libertad. Es un aspecto suyo. La fe de Jesús en el amor de su Padre ha hecho de él un hombre extraordinariamente creativo. Descubrió al Creador en su creación y se sumó a su obra. Jesús fue un poeta, un creativo por excelencia (23). Con su imaginación pudo inventar los gestos para liberar a enfermos y pecadores. Con parábolas ganó a simpatizantes y contrincantes. Él no ha venido a condenar, sino a sacar belleza incluso de las peores circunstancias. Un hombre creativo como Jesús pudo incursionar en un mundo amenazante sin vacilar, venciendo los miedos que lo intimidaban para que se sometiera a la repetitividad de las tradiciones de sus mayores. Y, por lo mismo, ha debido conocer la soledad de los artistas.

En un hombre creativo como Jesús, la fe y la razón se encuentran una en la otra para colaborar con el Creador en la configuración de un mundo nuevo. Este, sin embargo, no aparecerá sin lucha contra el mundo que oprime a los pobres y los culpa de su miseria, pero que tampoco tiene asegurado su éxito. Este llegará, sabemos, a través de la muerte y resurrección de Jesús, en virtud de la obra del Padre.

La obra de Cristo supone su pasión, pero no acaba de triunfar por la acción de Jesús sino por la del Padre que lo saca de la muerte. La pasión es consecuencia directa del anuncio del Evangelio del reino a aquellos que no esperan nada sino de Dios. Ella tiene una expresión exterior y un fundamento interior. Ella es consecuencia de la Encarnación del Hijo en un mundo empecatado que no puede reaccionar sino eliminando al que proclama la liberación de los marginados. Pero, además, exige reconocer en Cristo una experiencia interior de fe en el amor de Dios que lo sostiene hasta el final. Jesús padece la voluntad de su Padre, no porque crea que el Padre necesita que le crucifiquen un ser humano, a su propio Hijo, para salvar, sino porque está convencido de que Dios ama a la creación y a la humanidad gratuitamente y que él debe cumplir su misión evangélica anunciando a las víctimas del mundo, y también a los victimarios, que su Padre hará justicia sin necesidad de castigar a nadie.

Ha sido lamentable en la historia de la teología la inversión que por el año mil se produjo en la comprensión de la salvación cristiana. Hasta entonces había primado la visión "descendente" de esta, propia de los padres griegos, que enfatizaba lo que Dios hace por nosotros en Cristo. Desde entonces, sin embargo, predominó la visión "ascendente" que acentuó la importancia de la acción del hombre Jesús en la obra de la salvación, subrayándose el mérito humano de acuerdo al esquema jurídico del do ut des. B. Sesboüé ha estudiado la "desconversión" en la comprensión de la gratuidad de la cruz producida con Anselmo y la teoría de la satisfacción en adelante (24). Sobre el mecanismo antropológico de la compensación y en la clave medieval

(23) Cf. José Luis Espinel Marcos, La poesía de Jesús, Ed. San Esteban, Salamanca, 1986.

(24) Cf. Bernard Sesboüé et al., "Redención y salvación en Jesucristo", en Salvador del mundo. Historia y actualidad de Jesucristo. Cristología fundamental, Secretariado Trinitario, Salamanca, 1997, pp. 120-121. 
del honor del señor, la teología construyó una explicación de la cruz de Cristo que, si en Anselmo todavía quería explicar la misericordia de Dios, en el futuro llegará a formularse como satisfacción penal, como castigo necesario del Padre al Hijo para la redención de los pecados.

Una tal explicación de la cruz, descaminada del Evangelio, ha podido contribuir a dos monstruosidades teológicas estrechamente vinculadas. Por una parte ha llevado a concebir al Cordero de Dios como un animal capaz de propiciar la salvación con su mero sacrificio corporal. Esto ha ocurrido cuando se ha olvidado que la "sangre" de Cristo que de veras logra la salvación, es la de quien ha entregado libre y voluntariamente su vida. La sangre de Cristo no tiene ningún valor mitológico. Si lo único que ha importado es que Cristo sea castigado en nuestro lugar para merecer por nosotros, bien podría prescindirse de su predicación del amor de Dios a los pobres y de la experiencia interior de fe del Hijo en la bondad de su Padre. ¿O acaso no es la negación misma de la fe en Dios que alguien pueda someterse a un Dios que castiga para compensar con su penitencia el daño causado por el pecado? La negación de la gratuidad del amor de Dios hace imposible la fe de Cristo, la de los pobres y la de cualquiera.

Por otra parte, en estrecha relación con lo anterior, la comprensión "compensatoria" de la cruz fácilmente ha podido llevar a pensar que los pobres, y todas las víctimas del mal del mundo, merecen lo que padecen. Jesús en la cruz, víctima de la condena a muerte más ignominiosa, ciertamente ha hecho pensar a sus contemporáneos que él era culpable de tal pena. Los jefes de la nación, los expertos en Dios, lo juzgaron reo de muerte. ¿Habrán dudado sus más cercanos? ¿Habrán pensado que fue imprudente? Es probable. Ha sido muy normal en todo tiempo imaginar que a los que les va bien en la vida, es Dios que los bendice. Su castigo, por el contrario, parece evidente en los desgraciados. La perversión de estas explicaciones sacrificialistas de la cruz estriba en que, al erradicar la gratuidad del amor salvador de Dios, en un continente como el latinoamericano, por ejemplo, hace culpables a los inocentes y libera de culpa a los que se ajustan a la religiosidad que mediatiza el temor de un "Dios" que premia y que castiga. En América Latina suele decirse que "los pobres son flojos". De las víctimas de las violaciones de los derechos humanos se ha afirmado "algo habrán hecho". Pues bien, solo la fe de Jesús en un Padre que no castiga, en un Dios que lo ama a él y al mundo gratuitamente, que solo puede querer la vida de sus criaturas, puede liberar a pobres y pecadores del estigma fatal con que se los clasifica. Si Jesús no ha creído en la bondad de Dios, la fe de los pobres sería una ilusión fatua.

Los pobres no necesitan que Dios se vengue contra los "ricos" para su liberación. La venganza arruina a los pobres, y a Dios lo desacredita por completo. Dios no se venga. Dios no castiga. Esta conclusión está implícita en el reino que Jesús ha proclamado a pobres y pecadores. De ella depende la liberación de unos y otros. Ella habría sido imposible, empero, si Jesús no hubiera experimentado el amor gratuito del Padre por él. En el otro extremo de las posibilidades está la explicación completamente loca que enseña que el sacrificio del Hijo complace a Dios en orden a nuestra salvación. El sacrificio del Hijo "ha sido necesario" (cf. Lc 24, 26), por cierto, porque no habría sido posible que Jesús asumiera las "razones para no creer" de su pueblo sin sufrir las consecuencias de sus palabras y acciones. Pero no ha sido Dios, sino los pecadores los que han inferido al Hijo un castigo que, a los ojos de Dios, ni siquiera 
ellos merecen por crucificarlo. A Jesús no lo asesinó su Padre y su Padre tampoco ha consentido en ello. Lo mataron los que mantenían al pueblo en la desconfianza mediante una religiosidad piramidal y excluyente, y los que los oprimían política y económicamente. Dicho en otros términos, la fe de Jesús primero fracasó y solo después triunfó sobre la "fe" de los expertos religiosos de Israel. La fidelidad "voluntaria" del Cordero a la voluntad del Padre, ha manifestado incluso que nada hay más amenazante para la religiosidad compensatoria y ritualista que la fe en Dios.

Nadie que crea que Dios castiga puede tener fe auténtica. Si nunca hubiera habido fe auténtica no tendríamos cómo saberlo. Pero sí la ha habido. Este es un hecho. Lo otro una hipótesis. Jesús creyó. María le enseñó a creer. La idea de un castigo divino ha podido impedir teóricamente la fe de Jesús y concretamente, tantas veces, ha impedido la fe de los cristianos. Nada ha habido más perjudicial para la vida cristiana que reducir a Dios al mecanismo antropológico compensatorio que obliga a articular la espiritualidad y la moral bajo el supuesto de que seremos premiados o castigados según nuestras obras. Los textos del Nuevo Testamento que reproducen esta mentalidad, deben ser interpretados de acuerdo a la analogia fidei que impide claudicar de la gratuidad de la salvación. El mismo Juicio Final, dato escatológico inextirpable del credo de la Iglesia a riesgo de banalizar el amor de Dios y del cual depende la esperanza de justicia de víctimas inocentes, es preciso entenderlo en esta clave. También el mérito católico que Trento obliga a reconocer, no puede sino tener lugar al interior, a causa de y como condición de verificación del amor de un Dios que no necesita sacrificios humanos para salvar, sino que por amar gratuitamente, puede despejar a la moral y a la espiritualidad cristiana el camino de un amor incluso más grande que el mandado por la Ley o las autoridades eclesiales. El mérito católico estriba en participar en el mérito del Cristo que, con su sacrificio amoroso y gratuito, abolió todo tipo de sacrificios humanos y de castigos. Al resucitar a Jesús, el Padre no aprueba el sacrificio que Caifás y los demás hicieron de él, sino la entrega voluntaria que Jesús hizo de su vida.

La resurrección constituye el triunfo de la fe de Jesús. Dios, en ella, rehabilita la justicia de su causa, honra su inocencia y evidencia la iniquidad de los que lo condenaron a muerte. Jesús creyó en Dios. Dios no lo defraudó. Jesús no pudo salvarse a sí mismo. Como un hombre verdadero no pudo hacer más por el reino al que dedicó su vida. A lo más pudo morir por él. Pero su reino prosperará por la acción gratuita de su Padre. No ha sido el poder de un hombre, menos aún la fuerza bruta, sino el amor de Dios, la fuerza del Espíritu, que lo resucitó. Si el miedo alguna función positiva puede cumplir en la salvación del hombre, es como advertencia del fracaso propio o ajeno.

La fe de Jesús abrió una historia que un día Dios mismo tendrá que cerrar. Jesús no solucionó el problema del mal ni en la teoría ni en la práctica. Simplemente padeció los males de su tiempo y apostó a que Dios se encargaría de ellos. Desde entonces a Dios toca cumplir la apuesta. El grito de Jesús "Dios mío por qué me has abandonado", es el grito de fe del representante de los hombres y mujeres que se encomendaron a Dios y murieron sin que su oración fuera escuchada. El grito de Jesús devuelve al mundo la esperanza. Jesús apuesta a que algún día su Padre hará justicia, a que el mundo tiene razón de ser y puede ser mejor. Porque Jesús rezó confiadamente a su Padre, ha podido alentar a los que rezan. Él sabe y enseña que 
"Dios dará cosas buenas a sus hijos". No serán las obras -como bien entendió San Pablo- sino la fe que Cristo resucitado infundió a los suyos mediante el Espíritu, la que obtendrá la respuesta favorable de Dios. La de Jesús es rebeldía contra la fatalidad y apuesta por la libertad de Dios para hacer "nuevas todas las cosas", precisamente cuando las apariencias indican que Él y la fatalidad son lo uno y lo mismo. Todo está pendiente. Dios que cumplió la apuesta de Jesús en su caso, todavía tiene que cumplirla en el nuestro.

Es sorprendente que el Hijo, que es uno con el Padre, haya tenido fe en Él. Este es el misterio de una Encarnación que efectivamente se realiza en kénosis histórica. Sorprendente ha sido también que el Hijo haya creído en los demás. La Encarnación comprendida a cabalidad y en el plano que aquí interesa, lleva a captar la hondura de la realización histórica de la fe de Jesús. Bien podemos imaginar que de la fe de Jesús en Dios, depende la recuperación de la fe de Dios en los hombres. Jesús merece la confianza de Dios y merece la confianza de los hombres. Jesús es el mediador de la salvación por la fe. El don gratuito y reconciliador de Dios en Jesús a los hombres, ha hecho posible la fe de los hombres "en" su Padre y "en" sí mismos, sin confundir pero tampoco separar una y otra. El Espíritu que suscitó en Jesús la confianza en el amor de Dios, guía a los cristianos a hacer las mismas obras gratuitas de Jesús e incluso mayores. Porque las obras no obtienen la salvación pero, cuando son gratuitas, verifican la fe en el amor de Dios.

\section{LA FE DE DIOS}

Al resucitar a Jesús, teológicamente hablando, Dios recupera la confianza de los pobres de su pueblo y, en principio, gana la confianza del resto sufriente de la humanidad. Al hacerlo, Dios acredita a Jesús como el creyente por excelencia: el hombre que creyó no fue defraudado. Pues bien, en este hombre creyente, en Jesús, creyó la Iglesia. De aquí que la fe de la Iglesia "en" Cristo radica en la fe "de" Jesús. Ya hemos explicado por qué razones la Iglesia pudo creer en un hombre y en un crucificado. Que haya podido creer en un hombre crucificado sin interioridad, constituye, en cambio, una rareza que no tiene explicación racional alguna. Como se ha dicho más arriba, la imagen de Jesús como el Cordero no sirve si con ello se reduce a Cristo a un animal sacrificable. El apolinarismo abrazaría fervoroso semejante idea, pues un hombre sin alma humana -un ser sin autonomía para orientar su vida bajo el régimen de la fe y del discernimiento espiritual- gozaría automáticamente de la inocencia de un cordero cualquiera. Pero creer en un cordero rebajaría a la fe cristiana por debajo del triunfo del monoteísmo sobre la monolatría y el politeísmo. Y ciertamente traicionaría la confesión de Calcedonia. Pues tampoco serviría exigir fe para el Logos, si no se reconoce realmente que en la Encarnación el Logos asume un hombre verdadero y no solo un cuerpo humano.

Llevadas las cosas al plano de la interioridad, hemos inferido que la fe de Jesús no habría sido posible sin la experiencia de ser amado por su Padre. Y es en tal relación que descubrimos que el amor auténtico, en vez de apoderarse de los demás, los libera, espera de ellos, cree en ellos. Jesús ha creído en su Padre porque su Padre ha creído en él. En el otro extremo de la relación descubrimos que es la fe de Jesús 
en Dios la que hace también posible la fe de Dios en Jesús. Jesús merece la confianza de Dios para sí y para sus hermanos. Jesús, como representante de los que no tienen razones para creer y de los que sí las tienen, con su fe, consigue que Dios crea en él y despeja el camino a que Dios crea nuevamente en la humanidad. Esta es la consecuencia última de una Encarnación que acaba en la Nueva Alianza: en virtud de Cristo, Dios vuelve a confiar en su pueblo y mediante el don del Espíritu lo capacita para una fidelidad que está muy por encima de sus fuerzas (Jer 31, 31-33; Ezequiel 36, 33-36). Desde entonces se puede decir que Dios cree en la humanidad y cree en la Iglesia. Evidentemente que no se trata de la misma fe. Hablamos en términos análogos. La circularidad entre la fe del hombre en Dios y la fe de Dios en el hombre, tiene como origen el amor de Dios que pone en movimiento el circuito de la fe. Pero, por otra parte, fe propiamente tal es una actitud humana hacia Dios, más que un comportamiento de Dios hacia el hombre.

Hecha esta salvedad, analizamos a continuación qué alcances tiene para la creación que Dios crea en ella. Adelantamos el dato teológico fundamental: contra todo marcionismo que separa al Salvador del Creador, la afirmación de la fe de Dios equivale a reconocer el valor que tiene la razón humana en la tarea de llevar el mundo a la plenitud que Dios ha querido darle (25). El asunto aquí será ver en qué consiste que Dios crea en la humanidad y en la Iglesia.

\section{a) Dios cree en el hombre}

Dios cree en el hombre, pero no en uno cualquiera. Porque Dios ama a todas sus criaturas, quiere que la humanidad encuentre en Cristo su razón de ser. ¿Qué significa esto en un mundo extraño como el latinoamericano, tradicional en buena medida, pero también en proceso de modernización?

La discordia entre la modernidad y la Iglesia representa bien la honda tensión teológica subyacente. Por razones que no corresponde analizar aquí, el conflicto de la Iglesia con la modernidad ha hecho creer que Dios y el hombre compiten uno "contra" otro, alejándonos de la confesión calcedónica que indica que han de competir uno "con" otro, y que solo pueden entrar en conflicto a propósito del pecado. En otras palabras, la modernidad no es un "pecado" de la historia humana y, en consecuencia, los cristianos yerran cuando la condenan indistintamente. Así la Iglesia se resta a la obra histórica de Dios. La modernidad acarrea males, por cierto. Pero también es lamentable que la Iglesia encare el mundo moderno como si ella no perteneciera a este mundo. Solo a partir del dato sociológico y teológico de la mundanidad de la Iglesia, es posible emprender un discernimiento de la realización del hombre en tiempos de globalización de la modernidad.

Bien podría decirse que Dios no actúa en la Iglesia, sino en el mundo en el que la Iglesia actúa y en el mundo en cuanto Iglesia. La Encarnación no tiene lugar para salvar a la Iglesia, sino al mundo del cual la Iglesia representa la salvación escatológica. La modernidad expresa en la historia de la humanidad un aspecto de Cristo que la fe cristiana debe necesariamente reconocer como propio, esto es, la autonomía de

(25) Cf. Juan Noemi, El mundo, creación y promesa de Dios, San Pablo, Santiago, 1996, pp. 64-74. 
la razón de toda forma de heteronomía que haga del hombre un esclavo, incapaz de pensar y labrarse un futuro por sí mismo, un prisionero del miedo y de poderes que no reconocen su dignidad y libertad fundamental. En este sentido fe cristiana y razón moderna no se excluyen, se necesitan. En nuestro contexto es posible, en consecuencia, imaginar una modernidad católica o un catolicismo moderno (26). La razón moderna extravía su curso cuando, cerrada sobre sí misma, desemboca en un individualismo extremo y en la ilusión de un progreso que banaliza los límites inherentes a la humanidad y la muerte. Pero también la fe, desprendida de la razón moderna, conduce al mismo individualismo, trivializando, por el contrario, la vida contemporánea y su drama.

La cura del divorcio de fe cristiana y razón moderna debiera darse en la fragua de una cultura como ha podido ser la latinoamericana, abigarrada de símbolos de vida y de muerte, diversa en sus versiones comunitarias, pero abierta a las transformaciones propias de un mundo que Dios no se cansa de recrear (27). Porque es claro que cuando la modernidad olvida las raíces culturales y religiosas que le dieron origen u opera con un concepto mezquino de razón, pierde en definitiva su orientación humanista (28). Ocurre, por ejemplo, con las democracias reducidas a puros procedimientos, independientes de un ethos particular, que no tienen y no pueden ya ofrecer una imagen de mundo que compartir (29). Pero la cultura cristiana tradicional, cuando se blinda a nuevas síntesis, deja a sus pueblos al margen de la historia y del aporte moderno. No se puede descartar que como resultado del discernimiento que los hombres y las comunidades hacen de su destino, se estime que la modernización constituya una amenaza radical y, por tanto, haya que descartarla de plano. Pero tampoco se puede rechazar la cultura moderna como amenaza per se, porque la inculturación de la fe es una exigencia propia de un credo convencido de que Dios se ha identificado, en principio, con todas la culturas de la humanidad.

Dios cree en el hombre, el tradicional y el moderno. Pero lo más sorprendente es que Dios cree en el pobre. Hasta aquí podemos decir, en términos teológicos, que el Hijo se ha identificado con la humanidad en general. Se lo afirma normalmente con la expresión "Dios se ha hecho hombre". Pero el misterio de la Encarnación se verifica a través de la predicación del Evangelio a los pobres y de la muerte de la persona de Jesús, el Pobre, en la cruz. El Hijo de Dios se hace pobre para enriquecernos con su pobreza (cf. 2 Cor 8, 9). Dios cree en este hombre. Cree en los hombres que no son dignos de fe, sino sospechosos de culpabilidad. Dios reconoce como sus hijos e hijas preferidas, a los que no se da crédito, a los que no tienen fuerzas, recursos, títulos, salud ni privilegios. Es Dios que sustenta sus vidas como

(26) Cf. Eduardo Silva, "Catolicismo moderno y modernidad católica", en Samuel Yáñez y Diego García (eds.) El porvenir de los católicos latinoamericanos, Centro Teológico Manuel Larraín, Universidad Alberto Hurtado, Santiago, 2006, pp. 211-245.

(27) A propósito de la identidad latinoamericana, Jorge Larraín subraya que esta no puede concebirse como una esencia sellada de una vez para siempre en los siglos XVI y XVII, sino que ella permanece abierta a nuevas síntesis culturales (cf. Jorge Larraín Modernidad, razón e identidad en América Latina, Editorial Andrés Bello, Santiago, 1996).

(28) Esta ha sido preocupación recurrente de Benedicto XVI en su corto pontificado. Véase el discurso en la Universidad de Ratisbona (12 septiembre 2006).

(29) Cf. Juan Bautista Metz, Por una cultura de la memoria, Antropos, Barcelona, 1999, pp. 120-123. 
lo ha hecho con su propio Hijo. La esperaza de que un día Dios declarará su justicia, como lo hizo con Jesús, anima a los pobres a tejer la historia con hebras tradicionales y modernas, a luchar por una vida siempre esquiva o al menos a soportar las sociedades que los oprimen.

Ni la cultura tradicional ni la moderna alcanzan a ser cristianas, si no reconocen a los pobres como sujetos capaces de participar e incidir, con su propia cultura popular, en la construcción de sus sociedades. Los pobres pueden ser modernos, porque pueden liberarse de las opresiones culturales y religiosas que cohonestan su explotación o su marginación; porque tienen condiciones individuales de lucha por la vida, de autonomía, de ingenio y de sacrificio, de que otros carecen. Pueden ser también tradicionales, y comúnmente los pobres latinoamericanos así lo son, para descansar en la cultura de sus mayores y aprovechar de ella los recursos lingüísticos y simbólicos que les permiten reconocer su identidad popular, su pasado y el futuro que desean para sus hijos.

Bien podemos imaginar que la fe de Dios en Jesús estimula la esperanza de un mundo al revés. La edificación de una sociedad cristiana en la que los pobres sean verdaderamente protagonistas, se sustenta en que Dios crea en el proyecto histórico de Jesús de Nazaret, el reino anunciado a los que no son tomados en cuenta como personas. El reino de Dios ofrece al menos el horizonte de humanización al que debieran tender las sociedades que, en palabras de la Conferencia de Aparecida, son excluidos: los que "no son solo explotados, sino (también) sobrantes y desechables" $\left(n^{\circ} 65\right)$.

\section{b) Dios cree en la Iglesia}

Finalmente, en los términos hasta aquí usados, podemos decir que Dios cree en la Iglesia que está en el mundo sin ser del mundo. Como se ha dicho arriba, una Iglesia que no considere que ella es mundo, que se enfrenta especialmente a la modernidad como con un enemigo, fracasa porque así no contribuye a la salvación de la modernidad. Pero tampoco la Iglesia de Cristo se asimila tan fácilmente a cualquier cultura, nueva o antigua, porque el pecado es una realidad en ella y en el mundo, y porque la historia no ha terminado.

De aquí que podamos decir que Dios cree en la Iglesia que se halla en camino escatológico a convertir el mundo, del que forma parte, en el reino de Dios. La Iglesia es una realidad en proceso de conversión a Dios. No es su infalibilidad, sino su fragilidad y su labilidad las que conmueven a Dios. No es la Iglesia una megasecta que posea la verdad y a Dios mismo y que, por tanto, pueda sustraerse a la fatiga de creer día a día, de buscar y no hallar, de hallar y de perder, de angustiarse y de experimentar el consuelo y la paz del Cristo resucitado que, espiritual y no mecánicamente, la llama tras de sí. En una Iglesia en la que los fieles se acompañan unos a otros en la fe, el clero debiera cambiar. Sobre todas las cosas es necesario que sean hombres de fe, que confíen en Dios más que en su investidura o en la doctrina. En cuanto creyentes, no tendrían por qué saberlo todo y aprender de nadie. No debieran, por lo mismo, marcar distancias con el Pueblo de Dios al que también ellos pertenecen sino, por el contrario, estrechar el contacto espiritual que les permitirá escrutar la presencia de Dios en la vida humana. 
Cristo cree en la Iglesia. Cristo no necesita que su Iglesia crea en él para creer él en ella. Pero la Iglesia, arraigada en el tiempo, no puede pretender apropiarse de Cristo, y de la verdad y de la justicia. Solo puede creer en Cristo convirtiéndose a él incesantemente, atenta a los "signos de los tiempos" a través de los cuales el Espíritu va revelando el misterio de Cristo y en el entendido de que solo al fin de la historia se sabrá si ha sido la Esposa fiel o infiel del Señor, si sirvió o no a la conversión del mundo en el reino de Dios.

Lo que hoy se pide de la Iglesia es exactamente lo que le cuesta. Nada es más necesario en un continente que tiende a la fragmentación que afecta a las culturas, afectado por un pluralismo indiferentista y que no supera la injusticia que produce marginación y personas abandonadas, que la Iglesia sea en él sacramento de unidad con Dios y entre los seres humanos (LG 1). Ello lo cumple ofreciendo comunidades en las que es posible hacer la experiencia fundamental de fe en Dios, es decir, comunidades eclesiales de base en las cuales las personas se encuentren con Aquel que cree en ellas, el Dios que no teme a sus pruebas y equivocaciones. Para ello es necesario que la Iglesia se permita a sí misma experimentar lo que tiene que anunciar. Ella debe ser un hogar para los que no lo tienen o lo perdieron, una "madre" de familia que tiene por Dios a un Padre que la ama y no la amenaza. La pastoral del temor o del terror, aparentemente tan eficaz, apunta en la dirección contraria a la transmisión de la experiencia de fe en un Dios que es amor y que no necesita, en consecuencia, amenazar ni castigar para encaminar la historia. Tales comunidades son posibles donde la Iglesia, pastores y fieles, viven de la fe y no de un supuesto conocimiento exhaustivo de Dios.

Pero además de lo anterior, se hace necesario que la experiencia de fe que propicia comunidades fraternas se articule con las exigencias de la razón. La comunión en el amor no se agota en la intimidad de las pequeñas comunidades y estas arriesgan su pervivencia si la gran Iglesia no las orienta y corrige con una enseñanza que, en vez de extraer recetas fundamentales de la Sagrada Escritura o de la Tradición, media la fe viva del Pueblo de Dios con las tradiciones culturales concretas de los pueblos y las contribuciones también actuales de las ciencias modernas. Esta mediación es especialmente urgente para la opción por los pobres de la Iglesia latinoamericana. La teología de la liberación que en sus inicios pudo reducir la expresión de la fe a militancias políticas determinadas, en los últimos decenios ha corrido el peligro contrario de espiritualizar la causa de los pobres al grado de olvidarse de las mediaciones que se necesitan para modificar la historia. En cuarenta años ha menguado entre los latinoamericanos la esperanza de cambiar las estructuras sociales y de dar un rumbo voluntario a la historia.

La globalización en curso ha puesto en movimiento transformaciones tan grandes que es muy difícil decir quién sí y quién no es protagonista y agente de cambio social. El mundo se nos escapa de las manos. Diversos subsistemas (políticos, económicos, culturales, etc.) reclaman para sí terrenos autónomos y confinan a la Iglesia al espacio privado (30). Pero es la misma fe cristiana la que, en nombre del

(30) Cf. Pedro Morandé, "Sociedad contemporánea y persona", en Samuel Yáñez y Diego García (eds.) El porvenir de los católicos latinoamericanos, Centro Teológico Manuel Larraín, Universidad Alberto Hurtado, Santiago, 2006, p. 182. 
Creador, apela a la razón para no desesperar de la construcción de un mundo de personas irrepetibles e iguales en dignidad.

Hoy no podemos creer sin más en "la fuerza histórica de los pobres" (31). Esta nos confinaría a un tipo particular de fideísmo si pensáramos que basta el protagonismo de los pobres para edificar el reino en la tierra. El reino también se ofrece a los que no son pobres. Pero no basta el protagonismo de estos o aquellos. La historia, hasta donde nos es posible actuar en ella y darle alguna dirección, por un motivo de fe, ha de ser hecha con las mediaciones científicas y técnicas que la razón humana ha logrado producir. Los pobres no tienen futuro alguno -y desentenderse de ello constituye una irresponsabilidad- si no se cuenta con estas mediaciones y con el esfuerzo de los que no son pobres, para que el reino llegue.

A la Iglesia toca, nos parece, crear espacios comunitarios en los cuales, especialmente los pobres, puedan sentirse en su casa, creer en Dios y cambiar la realidad aunque sea en el entorno más próximo. Lo hará si se convierte en la Iglesia de los pobres (32). Y esto será posible cuando ajuste su organización y su enseñanza a las vidas concretas de las personas en las cuales el Espíritu de Dios actúa con o sin los pastores, con o sin la misma Iglesia. Distinta habrá de ser la Iglesia, y el mundo al que se debe, cuando en ella la fe de Jesús, el Pobre, sea mediada institucional y doctrinalmente.

\section{RESUMEN}

Lo que la Iglesia cree de Cristo, hunde sus raíces en el modo que tuvo Jesús de creer en Dios. Pero, a la vez, la fe de la Iglesia permite inferir cómo ha podido ser la experiencia espiritual de Jesús. Esta referencia recíproca entre Cristo y la Iglesia invita a indagar en los en los fundamentos antropológicos y teológicos de la fe "de" Jesús, en las dificultades y posibilidades que Jesús ha podido tener para creer en su Padre, puesto que así él enseña por qué y cómo han de creer también los hombres. Por esta vía descubrimos que el Padre, al resucitar a Jesús, triunfa sobre el Mysterium iniquitatis y, contra toda sospecha de indiferencia ante el sufrimiento humano que pudiera recaer sobre Él mismo, da pruebas de ser un Dios que merece fe. El Padre merece fe, pero no la merecería si Él no "creyera" también en la humanidad como "creyó" en su Hijo Jesús. Es el amor del Padre que en última instancia produce confianza en Él y entre los hombres.

Palabras clave: Fe de Jesús, cristología, fe.

\section{ABSTRACT}

What the Church believes of Christ finds its roots in Jesus' manner of believing in God. However, at the same time, the faith of the Church allows one to infer how the spiritual experience of Jesus came about. This reciprocal reference between Christ and the Church

(31) Gustavo Gutiérrez, La fuerza histórica de los pobres, [1979] Salamanca, 1982.

(32) Una de las convicciones más queridas de la teología de la liberación es anticipada por Alberto Hurtado, S.J., al decir: “... la Iglesia es la sociedad de los pobres, la ciudad para ellos construida. Esta ciudad de Dios en su primer plan ha sido construida para los pobres y aunque esta doctrina parezca extraña es verdadera" (s57y13a). Cf. Ignacio Ellacuría, "La Iglesia de los pobres, sacramento histórico de liberación”, Mysterium Liberationis, Trotta, Madrid, 1990, pp. 127-153. 
invites one to investigate the anthropological and theological tenets of the faith "of" Jesus, in the difficulties and possibilities that Jesus could have had in order to believe in his Father, given that he teaches us accordingly why and how to believe as well. In this way we discover that the Father, upon raising up Jesus, triumphs over the Mysterium iniquitatis and, against every suspicion of a possible indifference on the God's part in the face of human suffering, gives proof of being a God who deserves faith. The Father deserves faith, but he wouldn't if He did not also "believe" in humanity, just as He "believed" in his Son, Jesus. It is the love of the Father that, in the final analysis, brings about trust in Him and among people.

Key words: Faith of Jesus, Christology, Faith. 
